\title{
Calcineurin/Crz1 destabilizes Msn2 and Msn4 in the nucleus in response to $\mathrm{Ca}(2+)$ in Saccharomyces cerevisiae.
}

\section{$\operatorname{AUTHOR}(\mathrm{S}):$}

Takatsume, Yoshifumi; Ohdate, Takumi; Maeta, Kazuhiro; Nomura, Wataru; Izawa, Shingo; Inoue, Yoshiharu

\section{CITATION:}

Takatsume, Yoshifumi ...[et al]. Calcineurin/Crz1 destabilizes Msn2 and Msn4 in the nucleus in response to $\mathrm{Ca}(2+)$ in Saccharomyces cerevisiae.. The Biochemical journal 2010, 427(2): 275-287

\section{ISSUE DATE:}

2010-04-15

URL:

http://hdl.handle.net/2433/123771

\section{RIGHT:}

(C) The Authors Journal compilation (C) 2010 Biochemical Society; The Version of Record (VoR) is available at www.biochemj.org; 許諾条件により本文は2010-10-15に公開.; This is not the published version. Please cite only the published version.; この論文は出版社版で ありません。引用の際には出版社版をご確認ご利用ください。 
Sypplementary Table 1

\begin{tabular}{|c|c|c|c|c|c|c|c|}
\hline ORF & Gene $n$ & $\mathrm{CaFK} / \mathrm{Ca}$ & Position of CDRE-likt & Position of $\mathrm{S}$ & STRE & Localization & Function/Description \\
\hline YMR175W & SIP18 & 2.53 & & $-388-369$ & -158 & unknown & Phospholipid-binding protein; expression is induced by osmotic stress \\
\hline YKL035W & UGP1 & 2.41 & GGGGCGCA (-533) & $-483-445$ & $-272-260$ & cytoplasm; plasa membrane enriched fraction & $\begin{array}{l}\text { UDP-glucose pyrophosphorylase (UGPase), catalyses the reversible formation of UDP-GIc from glucose 1-phosphate and UTP, } \\
\text { involved in a wide variety of metabolic pathways, expression modulated by Pho85p through Pho4p }\end{array}$ \\
\hline YBR117C & TKL2 & 2.39 & & -77 & & cytoplasm; nucleus & $\begin{array}{l}\text { Transketolase, similar to TKl1p; catalyzes conversion of xylulose-5-phosphate and ribose-5-phosphate to sedoheptulose-7- } \\
\text { phosphate and glyceraldehyde-3-phosphate in the pentose phosphate pathway; needed for synthesis of aromatic amino acids }\end{array}$ \\
\hline YGR088W & CTT1 & 2.31 & & $-378-363$ & -133 & cytoplasm & Cytosolic catalase $T$, has a role in protection from oxidative damage by hydrogen peroxide \\
\hline YPL186C & UIP4 & 2.31 & & $-301-219$ & -95 & ER; nuclear envelope; mitochondrion & $\begin{array}{l}\text { Protein that interacts with UIp1p, a Ubl (ubiquitin-like protein)-specific protease for } \mathrm{Smt3p} \text { protein conjugates; detected in a } \\
\text { phosphorylated state in the mitochondrial outer membrane; also detected in ER and nuclear envelope }\end{array}$ \\
\hline YFL014W & HSP12 & 2.06 & GGGGCTG (-234) & $-435-414$ & $-377-232-190$ & plasma membrane; cytoplasm; nucleus & $\begin{array}{l}\text { Plasma membrane localized protein that protects membranes from desiccation; induced by heat shock, oxidative stress, } \\
\text { osmostress, stationary phase entry, glucose depletion, oleate and alcohol; regulated by the HOG and Ras-Pka pathways }\end{array}$ \\
\hline YOR173W & DCS2 & 2.03 & GGGGCTG $(-190)$ & $-160-148$ & & cytoplasm & $\begin{array}{l}\text { Non-essential, stress induced regulatory protein containing a HIT (histidine triad) motif; modulates } \mathrm{m} 7 \mathrm{G} \text {-oligoribonucleotide } \\
\text { metabolism; inhibits Dcs1p; regulated by Msn2p, Msn4p, and the Ras-cAMP-CAPK signaling pathway, similar to Dcs1p. }\end{array}$ \\
\hline YGR256W & GND2 & 2.00 & & $-299-163$ & & cytoplasm & $\begin{array}{l}\text { 6-phosphogluconate dehydrogenase (decarboxylating), catalyzes an NADPH regenerating reaction in the pentose phosphate } \\
\text { pathway; required for growth on D-glucono-delta-lactone }\end{array}$ \\
\hline YDR516C & EMI2 & 2.00 & & $-355-173$ & & cytoplasm & $\begin{array}{l}\text { Non-essential protein of unknown function required for transcriptional induction of the early meiotic-specific transcription factor } \\
\text { IME 1; required for sporulation; expression is regulated by glucose-repression transcription factors Mig1/2p }\end{array}$ \\
\hline YMR297W & PRC1 & 1.99 & & $-194-163$ & & cytoplasm; ER; vacule & $\begin{array}{l}\text { Vacuolar carboxypeptidase } Y \text { (proteinase } C \text { ), broad-specificity C-terminal exopeptidase involved in non-specific protein } \\
\text { degradation in the vacuole; member of the serine carboxypeptidase family }\end{array}$ \\
\hline YNL160W & YGP1 & 1.97 & & -434 & & extracellular region & $\begin{array}{l}\text { Cell wall-related secretory glycoprotein; induced by nutrient deprivation-associated growth arrest and upon entry into stationary } \\
\text { phase; may be involved in adaptation prior to stationary phase entry; has similarity to Sps } 100\end{array}$ \\
\hline YOR 382W & FIT2 & 1.93 & GGGGCTT (-420) & -242 & & cell wall & $\begin{array}{l}\text { Mannoprotein that is incorporated into the cell wall via a glycosylphosphatidylinositol (GPI) anchor, involved in the retention of } \\
\text { siderophore-iron in the cell wall }\end{array}$ \\
\hline YCL042W & & 1.92 & GAGGCTG (-441) & -449 & & cytoplasm & Putative protein of unknown function; epitope-tagged protein localizes to the cytoplasm \\
\hline YBR183W & YPC1 & 1.89 & & $-361-270$ & -83 & ER & $\begin{array}{l}\text { Alkaline ceramidase that also has reverse (CoA-independent) ceramide synthase activity, catalyzes both breakdown and } \\
\text { synthesis of phytoceramide; overexpression confers fumonisin B1 resistance }\end{array}$ \\
\hline YPL004C & $\angle S P 1$ & 1.83 & & $-215-193$ & -182 & cytoplasm; mitochondrion & $\begin{array}{l}\text { Primary component of eisosomes, which are large immobile patch structures at the cell cortex associated with endocytosis, along } \\
\text { with Pillp and Sur } 7 p \text {; null mutants show activation of } P \text { kc1p/ } / Y \text { pk1p stress resistance pathways }\end{array}$ \\
\hline YGR 052W & FMP48 & 1.82 & & -338 & & mitochondrion & $\begin{array}{l}\text { Putative protein of unknown function; the authentic, non-tagged protein is detected in highly purified mitochondria in high- } \\
\text { throughput studies; induced by treatment with 8-methoxypsoralen and UVA irradiation }\end{array}$ \\
\hline
\end{tabular}




\begin{tabular}{|c|c|c|c|c|c|c|}
\hline ORF & Genent & CaFK/Ca & Position of CDRE-lik & Position of STRE & Localization & Function/Description \\
\hline YNR001C & CIT1 & 1.81 & & $-159-134$ & mitochondrion & $\begin{array}{l}\text { Citrate synthase, catalyzes the condensation of acetyl coenzyme A and oxaloacetate to form citrate; the rate-limiting enzyme of } \\
\text { the TCA cycle; nuclear encoded mitochondrial protein }\end{array}$ \\
\hline YOL052C-A & DDR2 & 1.77 & & (-472-248-203-175 & cytoplasm; vacuole & Multistress response protein, expression is activated by a variety of xenobiotic agents and environmental or physiological stresses \\
\hline YBR 105C & VID24 & 1.76 & & -356 & cytoplasmic membrane-bounded vesicle; extrinsic t & $\begin{array}{l}\text { Peripheral membrane protein located at Vid (vacuole import and degradation) vesicles; regulates fructose-1,6-bisphosphatase } \\
\text { (FBP ase) targeting to the vacuole; promotes proteasome-dependent catabolite degradation of } F B P \text { ase }\end{array}$ \\
\hline YKL150W & MCR1 & 1.71 & & $-308-268$ & mitochondrion & Mitochondrial NADH-cytochrome b5 reductase, involved in ergosterol biosynthesis \\
\hline YDR 070C & FMP16 & 1.68 & & -201 & mitochondrion & $\begin{array}{l}\text { Putative protein of unknown function; proposed to be involved in responding to conditions of stress; the authentic, non-tagged } \\
\text { protein is detected in highly purfified mitochondria in high-throughput studies }\end{array}$ \\
\hline YMLO04C & GLO1 & 1.67 & GGGGCTT (-228) & $-432-229$ & cytoplasm; nucleus & $\begin{array}{l}\text { Monomeric glyoxalase I, catalyzes the detoxification of methylglyoxal (a by-product of glycolysis) via condensation with } \\
\text { glutathtione to produce S-D-lactoylglutathione; expression regulated by methylglyoxal levels and osmotic stress }\end{array}$ \\
\hline
\end{tabular}

